\title{
Association between antibody status to bovine herpesvirus 1 and quality of milk in dairy herds in Poland
}

\author{
J. G. Rola, ${ }^{\star 1}$ M. Larska, † M. Grzeszuk, $\ddagger$ and J. Rola† \\ *Department of Hygiene of Food of Animal Origin, National Veterinary Research Institute, Al. Partyzantow 57, 24-100 Pulawy, Poland \\ †Department of Virology, National Veterinary Research Institute, Al. Partyzantow 57, 24-100 Pulawy, Poland \\ ¥Spomlek Dairy Cooperative, ul. Gen. F. Kleeberga 12, 21-300 Radzyn Podlaski, Poland
}

\section{ABSTRACT}

Bovine herpesvirus 1 (BoHV1) is one of the most important pathogens of cattle; however, its effect on somatic cell count and milk components is not completely understood. The aim of the current study was to examine the effect of BoHV1 infection on quality of bovine bulk tank milk (BTM). A total of 1,790 individual blood samples collected at 28 dairy farms were used to determine the BoHV1 infection status of the herds with ELISA tests. The quality parameters of milk were evaluated by instrumental methods with BTM samples collected at monthly intervals from May 2011 to May 2012. The statistical analysis was performed to study the associations between BoHV1 herd status, quality of BTM, and herd-specific parameters. The risk factors influencing bulk milk somatic cell count (BMSCC) were estimated using the multivariable mixedeffects maximum likelihood regression model. The true prevalences of BoHV1 infection at the animal and herd levels were 49.3 and $64.6 \%$, respectively. The average BMSCC differed significantly between the herds grouped accordingly to their BoHV1 infection status. Interestingly, the highest BMSCC was observed in the vaccinated herds $\left(240.3 \times 10^{3}\right.$ cells $\left./ \mathrm{mL}\right)$. Additionally, the BoHV1 herd status had a significant effect on the fat content of BTM. The largest herds that were investigated had a BoHV1 seroprevalence over $30 \%$. The herd status was considerably influenced by the numbers of cows in the herds. Besides, no significant differences in total bacterial count or protein content in milk from BoHV1-infected und uninfected herds were observed. An increase in BMSCC was observed during summer compared with the winter months regardless of the BoHV1 status of the herds. In the final multivariable regression model, the main risk factors associated with BMSCC were BoHV1 herd status, the percentage of BoHV1 infected animals in a herd, the number of cows

Received August 25, 2014.

Accepted November 2, 2014.

${ }^{1}$ Corresponding author: jolarola@piwet.pulawy.pl in a herd, and the season. Our study suggests that BoHV1 infection may influence BMSCC levels, which are key parameters of BTM quality and a reference for subclinical mastitis in a herd. In conclusion, BoHV1 infection may cause economic losses by decreasing both quantity and quality of milk.

Key words: bovine herpesvirus 1, bulk tank milk, somatic cell count

\section{INTRODUCTION}

Bovine mastitis is one of the most economically important diseases affecting the dairy cattle sector all over the world. It is characterized by physical, chemical, and, usually, microbiological changes in the milk and pathological lesions in the glandular tissue of the udder (Sharma, 2007). Subclinical mastitis is still the most prevalent form of mastitis causing the greatest economic losses in spite of intensive research and implementation of various control programs (Pyörälä, 2003). Cows with subclinical mastitis are difficult to detect due to the absence of visible symptoms of infection. Currently, according to the recommendations of the International Dairy Federation (1999), subclinical mastitis is diagnosed based on milk SCC.

The primary agent of mastitis is a wide spectrum of bacterial strains; however, incidences of viral-, mycoplasmal-, algal-, and fungal-related mastitis have also been reported (Barkema et al., 2009). Bovine herpesvirus 1 (BoHV1), responsible for infectious bovine rhinotracheitis (IBR), infectious pustular vulvovaginitis in cows, and infectious pustular balanoposthitis in bulls, is presumably associated with mastitis (Wellenberg et al., 2002). Following an acute infection, BoHV1 establishes a latent infection, and after reactivation caused by stress factors it is re-excreted and can infect susceptible animals. Therefore, once infected, animals must be regarded as lifelong potential shedders of the virus (Pastoret et al., 1982). Bovine herpesvirus 1 causes significant economic losses, mainly attributable to reduced milk production, reproductive failure, abortions, increased calf mortality, and restrictions in 
the international trade of livestock (Nandi et al., 2009). The virus has the ability to induce immunosuppression by impairing the cellular immune response, which may theoretically increase the risk of mastitis as well (Jones and Chowdhury, 2010). Although BoHV1 infections are globally distributed, significant differences in regional incidences and prevalences were found. The average seroprevalences of BoHV1 infection in the United States, Canada, Australia, and New Zealand are very high (Ackermann and Engels, 2006). The European countries of Austria, Denmark, Finland, Norway, Sweden, and Switzerland are officially free of IBR. The seroprevalences of BoHV1 in other European countries range from $14 \%$ in Lithuania (Jacevičius et al., 2008) to $83 \%$ in southwest England (Woodbine et al., 2009). Eradication of IBR is often based on vaccination with glycoprotein E ( $\mathbf{g E}$ )-deleted marker vaccines. In Poland, $37.7 \%$ of dairy cows and $73.7 \%$ of dairy cattle herds were positive for BoHV1 antibodies (Rola et al., 2005). In Poland, bulls at the national semen-collection centers are free from BoHV1 infections; however, no official IBR-eradication program was established in dairy herds. The aim of the current study was to examine the effects of BoHV1 infection on quality of milk produced in dairy herds in eastern Poland.

\section{MATERIALS AND METHODS}

\section{Dairy Herds}

Farms with more than 10 cows, controlled for milk performance and located in eastern Poland, were selected for the present study. Twenty-eight out of 40 farmers who received information concerning our study agreed to participate. All of the farms supplied milk to the Spomlek Dairy Cooperative (Radzyn Podlaski, Poland). The size of dairy farms ranged from 24 to 186 (average 64) milking cows of the Holstein-Friesian breed. Cows were managed in open-stabling systems and fed using TMR technology. Eight of the 28 herds were vaccinated with a BoHV1 $\mathrm{gE}$-deleted marker vaccine (Rispoval IBR-Marker Inactivatum, Pfizer, Louvain-laNeuve, Belgium). During the observation period, the farms were bound to follow the biosecurity measures that included quarantine and testing for BoHV1 of newly purchased cattle, limited access of visitors, and protective clothing for farm staff.

\section{BoHV1 Herd Status}

To determine the BoHV1 infection status of the farms, 1,790 individual blood samples from milking cows were collected in May 2011. Additionally, bulk tank milk (BTM) samples from all herds were col- lected 3 times during the period from May 2011 to May 2012. All samples were submitted to the laboratory within 2 working days after collection. Blood samples were centrifuged $\left(3,000 \times g\right.$ for $15 \min$ at $\left.4^{\circ} \mathrm{C}\right)$ and serum was collected and frozen at $-20^{\circ} \mathrm{C}$ until testing, whereas BTM samples were kept at $4^{\circ} \mathrm{C}$ not longer than 3 d. In unvaccinated herds, serum samples were tested with the commercial Idexx IBR glycoprotein B (gB)blocking ELISA test kit (Idexx, Montpellier, France) with a specificity of 99.8 (95\% CI: $99.4-100 \%)$. Briefly, $100 \mu \mathrm{L}$ of 1:2 diluted serum samples in dilution buffer serum samples, positive and negative control sera, were added to BoHV1-coated microplates and incubated for $2 \mathrm{~h}$ at $37^{\circ} \mathrm{C}$. Then, the microplates were washed 3 times with wash solution and $100 \mu \mathrm{L}$ of conjugate diluted 1:100 was added. After incubation $\left(30 \mathrm{~min}, 37^{\circ} \mathrm{C}\right)$ the microplates were washed again and tetramethylbenzidine (TMB) substrate was added. After 10 min of incubation at room temperature, the reaction was stopped by adding stop solution and the optical density was measured at $450 \mathrm{~nm}$. A sample was classified as positive when the sample/mean negative controls $(\mathbf{S} / \mathbf{N})$ ratio was less or equal to $50 \%$. In vaccinated herds, the Idexx IBR gE ELISA test kit with a sensitivity of 99.83 (95\%CI: 99.7-100\%) was used. A sample was defined as positive for antibodies to the $\mathrm{gE}$ glycoprotein of BoHV1 when the $\mathrm{S} / \mathrm{N}$ ratio was less or equal to 0.6. A herd was considered to be infected with BoHV1 if at least 1 serum sample was positive in the respective ELISA test. Antibodies to BoHV1 in BTM samples were detected with the Idexx IBR gE ELISA test kit. Milk sample was classified as positive for antibodies to the $\mathrm{gE}$ glycoprotein when the $\mathrm{S} / \mathrm{N}$ ratio was less or equal to 0.8. All tests were performed according to the manufacturer's instructions. The BoHV1 herd status was established by testing of individual sera, and the herds were consequently divided into 4 groups (Table 1).

\section{BTM Quality Parameters}

Analyses of bulk tank milk somatic cell count (BMSCC), total bacteria count (TBC), and fat and protein contents were performed based on the reports issued by the Resources Assessment Laboratory. All applied methods were validated and the qualifications of laboratory staff were confirmed by the Polish Centre for Accreditation (Warsaw, Poland). The BMSCC was determined by flow cytometry using a Fossomatic 5000 (Foss Electric, Hillerød, Denmark), TBC by flow cytometry with a BactoScan FC (Foss Electric), and fat and protein content by infrared spectrometry with a MilkoScan 6000 (Foss Electric) according to the manufacturer's instructions. The BTM samples from 
Table 1. Description and summarized statistic of the variables analyzed in the study

\begin{tabular}{|c|c|c|c|c|c|c|}
\hline \multirow[b]{2}{*}{ Abbreviation } & \multirow[b]{2}{*}{ Variable } & \multirow[b]{2}{*}{ Scale } & \multirow[b]{2}{*}{ Unit } & \multicolumn{3}{|c|}{ Value } \\
\hline & & & & Mean & $95 \%$ CI & Range \\
\hline BMSCC & Bulk milk SCC & Continuous & $\times 10^{3}$ cells $/ \mathrm{mL}$ & 215.0 & $206.8,223.3$ & $35-437$ \\
\hline TBC & Total bacteria count & Continuous & Bacteria/mL & 20.4 & $18.6,22.2$ & $10-174$ \\
\hline Protein & Protein bulk milk content & Continuous & $\%$ & 3.34 & $3.32,3.35$ & $2.92-4.00$ \\
\hline Fat & Fat bulk milk content & Continuous & $\%$ & 4.21 & $4.18,4.24$ & $3.31-5.17$ \\
\hline BoHV1 herd status & $\begin{array}{l}\text { Presence of bovine herpesvirus } 1 \text { (BoHV1) infections or } \\
\text { vaccinations in a herd defined by serological testing of } \\
\text { individual serum samples }\end{array}$ & Categorical & - & \multicolumn{3}{|c|}{$\begin{array}{l}\text { 0: Group A (all seronegative); } \\
\text { 1: Group B (all vaccinated; gB }+/ \mathrm{gE}-\text { antibodies }) \\
\text { 2: Group C ( }<30 \% \text { seropositive animals }) \\
\text { 3: Group D ( }>30 \% \text { seropositive animals })\end{array}$} \\
\hline BTM BoHV1 result & $\begin{array}{l}\text { Interpretation of results of bulk tank milk (BTM) testing by } \\
\text { infectious bovine rhinotracheitis (IBR) glycoprotein E ( } \mathrm{gE} \text { ) } \\
\text { antibody ELISA (Idexx, Montpellier, France) }\end{array}$ & Dichotomous & - & \multicolumn{3}{|c|}{$\begin{array}{l}\text { 0: uninfected (including vaccinated) with } \mathrm{S} / \mathrm{N}>0.8 \\
\text { 1: } \mathrm{BHV} 1 \text { infected with } \mathrm{S} / \mathrm{N} \leq 0.8\end{array}$} \\
\hline BTM S/N & $\begin{array}{l}\text { Sample/mean negative controls (S/N) ratio calculated from } \\
\text { the optical densities of results of BTM testing by IBR gE } \\
\text { antibody ELISA (Idexx) }\end{array}$ & Continuous & Ratio & 0.69 & $0.61-0.76$ & $0.09-1.05$ \\
\hline$\%$ BHV1 infected & $\begin{array}{l}\text { Percent of glycoprotein } \mathrm{B}(\mathrm{gB}) / \mathrm{gE} \text { seropositive milking cows } \\
\text { in a herd }\end{array}$ & Continuous & $\%$ & 24.3 & $20.5,28.1$ & $0-98.9$ \\
\hline Month & Month of BTM collection & Nominal & - & \multirow{3}{*}{\multicolumn{3}{|c|}{$\begin{array}{l}\text { 1: } 13 \text { (May 2011-May 2012) } \\
\text { 0: Summer (June-August) } \\
\text { 1: Autumn (September-November) } \\
\text { 2: Winter (December-February) } \\
\text { 3: Spring (March-May) } \\
\text { 0: Small (<49 milking cows per herd) } \\
\text { 1: Medium (between } 50 \text { and } 100 \text { cows/herd) } \\
\text { 2: Large ( }>100 \text { cows } / \text { herd) }\end{array}$}} \\
\hline Season & Season & Categorical & - & & & \\
\hline Herd size & Herd size & Categorical & - & & & \\
\hline Cow number & Number of cows in the herd & Continuous & - & 63.9 & $59.3,68.5$ & $24-186$ \\
\hline
\end{tabular}


all herds were tested monthly between May 2011 and May 2012 (13 time points).

\section{Statistical Analysis}

The true prevalences of BoHV1 antibodies at the individual cow and herd levels were estimated from the apparent prevalences using Rogan and Gladen (1978) correction. For further analysis, the database was organized at the herd level. The variables used in the analysis are presented in Table 1 . The associations between BoHV1 herd status and numerical variables, such as bulk milk parameters (BMSCC, TBC, fat and protein) and number of cows in a herd, were individually tested by Spearman's rank correlation coefficient $(\rho)$ and ANOVA using STATA software (StataCorp., College Station, TX).

To investigate whether BoHV1 herd status and other variables influenced BMSCC (adopted as a measure of BTM quality), normality of the residuals of the later was investigated by visual examination of the kernel distribution, normal probability plot, and by ShapiroWilk statistic $(\mathrm{W}=0.984 ; P=0.0004$ for all 364 observations). However, as the variation of subgrouped BMSCC values was significant, a natural logarithmic transformation $\left(\log _{e}\right)$ of the variable was used to approximate the normal distribution. A multivariable mixed-effects linear regression (xtmixed in STATA) using maximum likelihood $(\mathrm{ml})$ parameter estimation with BMSCC as a dependent variable was fit. The model was developed by backward elimination of nonsignificant $(P<0.05)$ variables. Univariable linear regression models computing intraclass correlation were used to estimate the associations between pairs of individual variables before the multilevel model building. The analyses were performed on the full data set $(\mathrm{n}=$ 364), including all 13 time points of BTM sampling. For all analyses, a $P$-value below 0.05 was considered significant.

\section{RESULTS}

From a total of 1,790 cows, 1,105 (61.7\%) gB antibodies were detectable and 681 sera $(61.6 \%)$ reacted positively in the IBR gE ELISA. All cows from 8 vaccinated herds $(\mathrm{n}=424)$ had $\mathrm{gB}$ antibodies only. Therefore, the true prevalence of BoHV1 infection in cows from unvaccinated herds was estimated at $49.3 \%$ (95\%CI: $46.7-52.0 \%$ ), as 681 out of 1,366 animals originating from unvaccinated herds had both $\mathrm{gB}$ and $\mathrm{gE}$ antibodies. Thirteen out of $20(65 \%)$ unvaccinated herds were found to be BoHV1 infected $(\mathrm{gB}+, \mathrm{gE}+$; 95\%CI: $43.3-81.9 \%)$. The herd BoHV1 true prevalence was estimated at $64.6 \%$ (95\% CI: $43.5-85.8 \%)$. All the vaccinated herds were $\mathrm{gE}$ negative, indicating the absence of BoHV1 infections.

The average bulk tank milk $\mathrm{S} / \mathrm{N}$ values of IBR $\mathrm{gE}$ ELISA were 0.92 (95\%CI: $0.89-0.95), 0.93$ (95\%CI: 0.91-0.96), 0.93 (95\%CI: $0.74-1.12$ ), and 0.19 (95\%CI: $0.17-0.21$ ) for the herds divided into the groups A to D, respectively (Figure 1). Group A was represented by 7 uninfected and unvaccinated herds, whereas group B (vaccinated/uninfected; $\mathrm{gB}+/ \mathrm{gE}$-), group $\mathrm{C}$ (infected with BoHV1 seroprevalence below 30\%; $\mathrm{gB}+/ \mathrm{gE}+)$, and group D (infected with BoHV1 seroprevalence over $30 \% ; \mathrm{gB}+/ \mathrm{gE}+)$ were represented by 8,6 , and 7 herds, respectively. High correlation between BTM S/N values and the percentage of BoHV1-infected herds $(\mathrm{gB}+/ \mathrm{gE}+)$ was found with Spearman $\rho=-0.80(P<$ 0.0001; Figure 2). However, in the case of herds where the percentage of BoHV1-infected cows was equal or below $8.9 \%$, BTM S/N values were above 0.8 and the results were interpreted as negative. The average percentages of $\mathrm{gB} / \mathrm{gE}$ seropositive cows in a herd were 1.2 (95\%CI: $0.5-1.9)$ and 73.0 (95\%CI: 62.1-84.0) for the herds with BTM S/N result considered negative and positive, respectively.

The highest average BMSCC was found in the vaccinated herds (group B), whereas the lowest was observed in the herds with BoHV1 seroprevalence $<30 \%$ (group C; Table 2). In addition, significant associations between BoHV1 herd status and BMSCC, milk fat content, and number of cows in herd were observed by

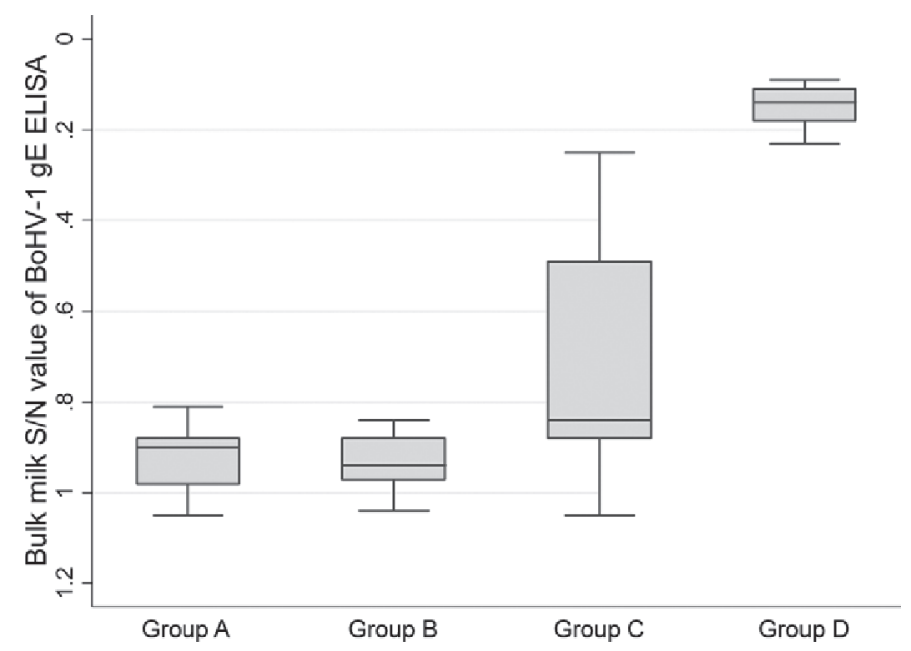

Figure 1. Box plots illustrating bulk milk sample/mean negative controls $(\mathrm{S} / \mathrm{N})$ values of Idexx infectious bovine rhinotracheitis (IBR) glycoprotein E (gE) ELISA test (Idexx, Montpellier, France) grouped accordingly to bovine herpesvirus 1 (BoHV-1) herd status (group $\mathrm{A}=$ seronegative; group $\mathrm{B}=\mathrm{gE}$-seronegative with vaccinations; group $\mathrm{C}$ $=<30 \%$ of herd seropositive; group D $=>30 \%$ of herd seropositive). Whiskers indicate the minimum and maximum values, the upper and lower side of the box represent 75 th and 25 th percentile. Median values are given in the boxes. 


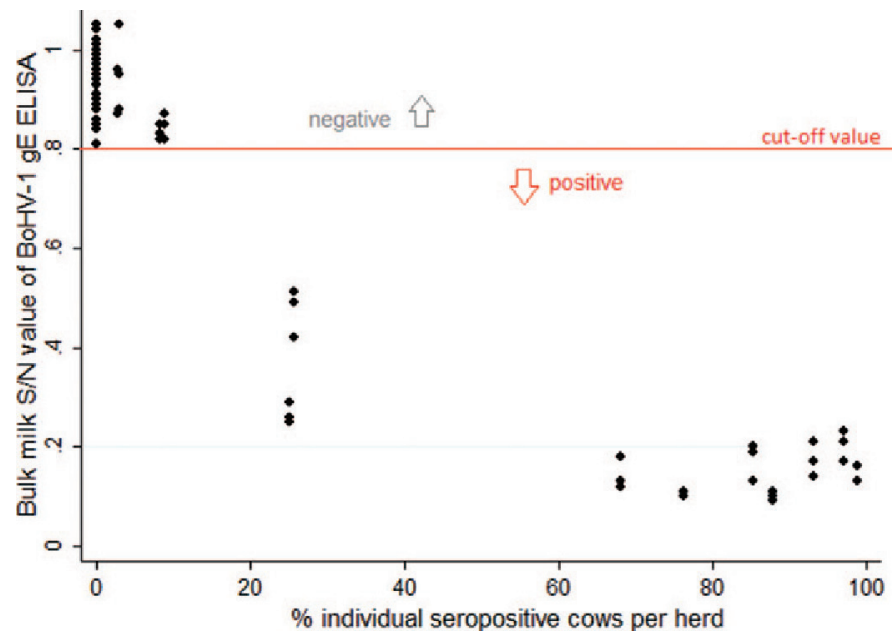

Figure 2. Relationship between bulk milk sample/mean negative controls $(\mathrm{S} / \mathrm{N})$ value of bovine herpesvirus 1 (BoHV-1) glycoprotein $\mathrm{E}$ ( $\mathrm{gE}$ ) ELISA and percentage of BoHV-1 infected (glycoprotein B/gE seropositive) cows in a herd. Color version available online.

univariable Spearman and ANOVA tests (Table 2). The distribution of BMSCC values over groups divided accordingly to BoHV1 herd status is presented in Figure $3 \mathrm{~A}$. The strongest correlation with the BoHV1 herd status was found for the number of cows in the herds with Spearman $\rho$ equal to $0.7(P>0.0001)$. The average size of the uninfected herds was 28.4 cows, compared with 98.9 heads in herds with seroprevalence above $30 \%$ (Table 2). Moreover, BMSCC was found to be significantly associated with the herd size $(P<0.0001)$, with average values of $231.0,198.3$, and $187.5 \times 10^{3}$ cells/ $\mathrm{mL}$ in small ( $\mathrm{n}=16$; average size 33.8 lactating cows), medium ( $\mathrm{n}=7$; average size 75.6 cows), and large $(\mathrm{n}=$ 5 ; average size 144 cows) herds, respectively.

The BMSCC was significantly influenced by the month of sampling (Figure 3) and, hence, by the season (Figure 2B; $P \leq 0.0001$ ). In the 12 -mo investigation period, the average BMSCC fluctuated independent of the BoHV1 herd status, with levels below $200 \times 10^{3}$ cells $/ \mathrm{mL}$ in the colder months from October $(190.0 \times$ $10^{3}$ cells $/ \mathrm{mL}$; 95\%CI: $180.1-241.4 \times 10^{3}$ cells $\left./ \mathrm{mL}\right)$ until February $\left(199.0 \times 10^{3}\right.$ cells $/ \mathrm{mL} ; 95 \%$ CI: $172.2-226.5$ $\times 10^{3}$ cells $\left./ \mathrm{mL}\right)$ to values close to $250 \times 10^{3}$ cells $/$ $\mathrm{mL}$ in the warm months from June $\left(243.8 \times 10^{3}\right.$ cells $/$ $\mathrm{mL}$; $95 \%$ CI: $214.6-273.1 \times 10^{3}$ cells $/ \mathrm{mL}$ ) until August $\left(237.6 \times 10^{3}\right.$ cells $/ \mathrm{mL} ; 95 \%$ CI: $206.4-266.3 \times 10^{3}$ cells $/$ $\mathrm{mL}$; Figure 4). Similar observations were obtained when the year was divided into 4 seasons with the highest and lowest average BMSCC in summer and winter, respectively (Figure 3B).

The final model with BMSCC as the outcome (developed by backward elimination of the variables that were not associated with BMSCC) included BoHV1

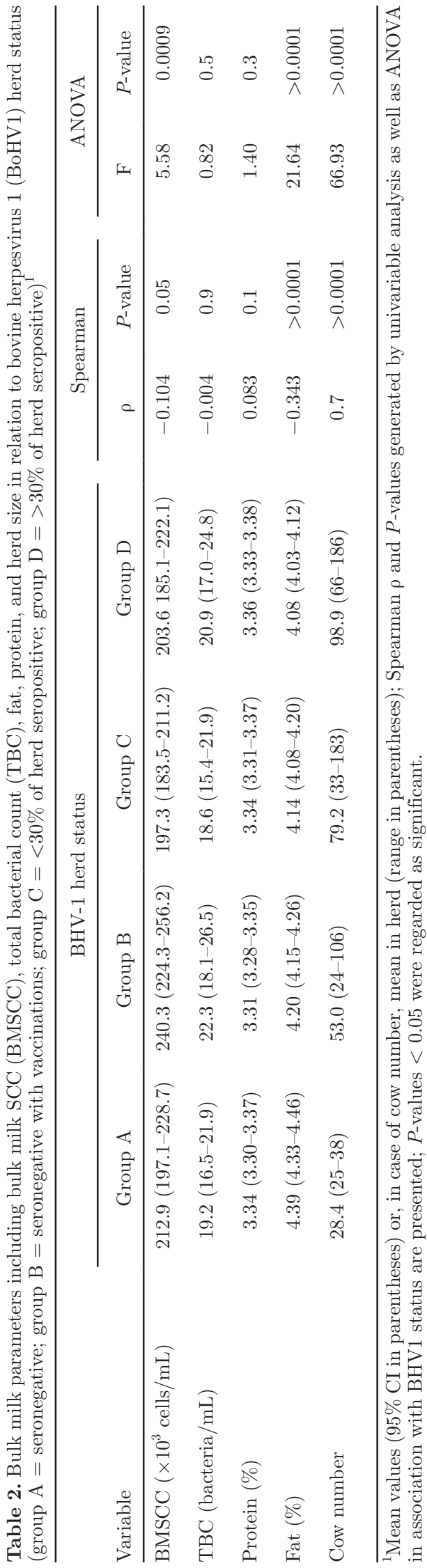

Journal of Dairy Science Vol. 98 No. 2, 2015 

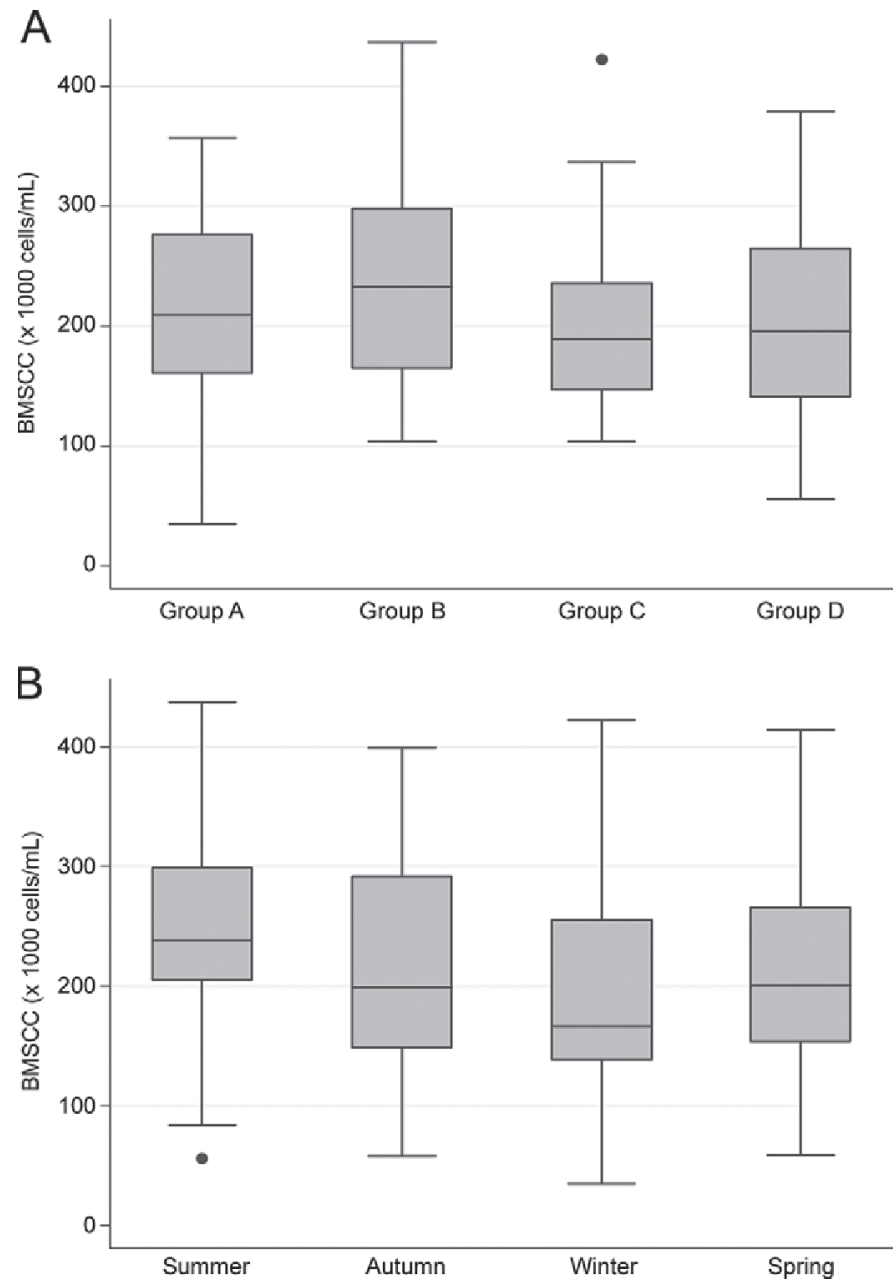

Figure 3. (A) Bulk milk SCC (BMSCC) by bovine herpesvirus 1 herd status (group $\mathrm{A}=$ seronegative; group $\mathrm{B}=$ glycoprotein E-seronegative with vaccination; group $\mathrm{C}=<30 \%$ of herd seropositive; group $\mathrm{D}=>30 \%$ of herd seropositive). A point ( $)$ indicates an outlier. (B) The BMSCC by season. The box plots represent minimum and maximum (whiskers), 75th and 25th percentile (upper and lower side of the box), and median (central line in the box).

herd status, number of cows in a herd, and percent of BoHV1-infected cows in a herd and season (Table 3). Significant positive association between BMSCC and origin from vaccinated herds (group B) as well as herds with less than (group C) and more than 30\% BoHV1 seropositivity (group D) with respect to uninfected herds (group A) was observed. Cows belonging to groups B and $\mathrm{C}$ had significant chances of increased BMSCC by approximately $2 \times 10^{3}$ cells $/ \mathrm{mL}$ in relation to uninfected herds, whereas the greatest effect was observed in the herds with the highest BoHV1 seroprevalence (group D), with significantly increased BMSCC by 120 $\times 10^{3}$ cells $/ \mathrm{mL}\left(\right.$ antilog of $\left.\log _{\mathrm{e}}=0.903\right)$. The number of cows in a herd had a negative effect on BMSCC, mean-

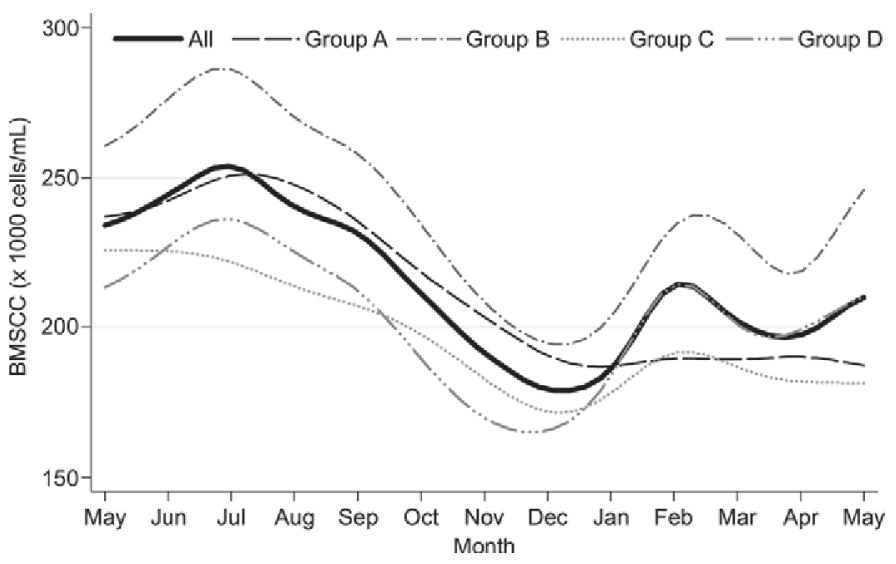

Figure 4. Lowess smoothed regression curve of the association between bulk milk SCC (BMSCC) and month of testing in respect to all herds and herds from group A (seronegative), group B (vaccinated glycoprotein E-seronegative), group $\mathrm{C}$ (herds with $<30 \%$ bovine herpesvirus 1 seroprevalence), and group D (herds with $>30 \%$ bovine herpesvirus 1 seroprevalence).

ing the larger the herd, the lower BMSCC recorded. The BMSCC decreased by approximately $1 \times 10^{3}$ cells / $\mathrm{mL}$ (antilog of $\log _{\mathrm{e}}=0.001$ ) when increasing number of cows in the herd by one. Due to the collinearity, the herd size was removed from the model. The percentage of BoHV1-infected cows had also a negative effect on BMSCC. A $1 \%$ increase of herd seropositivity resulted in a decrease of BMSCC by $2 \times 10^{3}$ cells $/ \mathrm{mL}$ (antilog of $\log _{\mathrm{e}}=0.010$ ). Despite the statistical significance, the coefficients of association of BMSCC and cow number and percent infected with BoHV1 were low in respect to other coefficients. In the model, season proved again to have significant effects on BMSCC, with the negative coefficients with respect to the mean value (Figure 3 ). According to the estimations, winter influenced the decrease of BMSCC in a herd by $4.23 \times 10^{3}$ cells $/ \mathrm{mL}$ (coefficient 0.272 ) in respect to the summer value.

\section{DISCUSSION}

The aim of the present study was to examine the effect of BoHV1 infection on the quality of milk in cattle. The prevalence of BoHV1 infection in unvaccinated dairy herds was determined on individual serum samples using IBR gB-blocking ELISA, which is one of the most sensitive and specific tests for the detection of antibodies in serum. In our study, over $49 \%$ of cows and $64 \%$ of herds were shown to be infected with BoHV1. These results indicate that the percentages of BoHV1infected animals and of infected dairy herds were higher and lower, respectively, than in the study of Rola et al. (2005). However, it should be noted that our study 
Table 3. Final multivariable mixed-effects maximum likelihood regression model $(P<0.0001)$ of the association between bulk milk SCC (BMSCC) transformed into natural logarithm $\left(\log _{\mathrm{e}}\right)$ and bovine herpesvirus 1 (BoHV1) herd status (group $\mathrm{A}=$ seronegative; group $\mathrm{B}=$ vaccinated glycoprotein E-seronegative; group $\mathrm{C}=<30 \%$ of herd seropositive; group $\mathrm{D}=>30 \%$ of herd seropositive), cow number per herd (range 24-186), percent of BoHV1 infected (glycoprotein B/glycoprotein E seropositive) cows in a herd, and season ${ }^{1}$

\begin{tabular}{lccccc}
\hline BMSCC $\left(\log _{\mathrm{e}}\right)$ & Coefficient & $\mathrm{SE}$ & $z$ & $\mathrm{P}>|z|$ & $95 \%$ CI \\
\hline BoHV1 herd status & & & & & - \\
Group A & 0 & - & - & - & 0.002 \\
Group B & 0.176 & 0.564 & 3.12 & $0.065,0.287$ \\
Group C & 0.158 & 0.071 & 3.22 & 0.026 & $0.018,0.296$ \\
Group D & 0.903 & 0.263 & 3.43 & 0.001 & $0.386,1.420$ \\
Cow number & -0.001 & 0.0006 & -2.51 & 0.012 & $-0.003,-0.0003$ \\
\% BoHV1 infected & -0.010 & 0.003 & -3.26 & 0.001 & $-0.016,-0.004$ \\
Season & & & & & - \\
Summer & 0 & - & - & - & $-0.291,-0.061$ \\
Autumn & -0.177 & 0.003 & -3.01 & 0.003 & $-0.387,-0.157$ \\
Winter & -0.272 & 0.059 & -4.64 & $<0.001$ & $-0.277,-0.062$ \\
Spring & -0.169 & 0.055 & -3.09 & 0.002 & $5.369,5.590$ \\
Intercept & 5.479 & 0.057 & 96.96 & $<0.001$ & \\
\hline
\end{tabular}

${ }^{1}$ Number of observations $=364 ; P$ values $<0.05$ were regarded significant, $z=z$ factor, standard score.

included a relatively small number of dairy herds from eastern Poland and current prevalence of BoHV1 infection in the cattle population may be different. Using bulk milk samples, the seroprevalence of BoHV1 in 186 herds in Thailand (Kampa et al., 2009) and 60 herds in Peru (Ståhl et al., 2002) was established at 61 and $51 \%$, whereas a larger Estonian study (Raaperi et al., 2010) including over 1,200 dairy herds showed BHV1 seroprevalence of $22 \%$.

In addition to serum, BTM samples were tested with the IBR gE-specific ELISA. Milk testing is a simple and inexpensive alternative to individual serum testing and it is generally used to screen the BoHV1 infection status of dairy herds. However, the sensitivity of gEspecific ELISA for milk compared with other diagnostic ELISA tests is low and may give false negative results. Wellenberg et al. (2002) showed that bulk milk was positive in IBR gE ELISA when at least 10 to $15 \%$ of cows in the herd were infected with BoHV1. Similar conclusions were made by Kramps et al. (2004), who evaluated different tests for the detection of antibodies to BoHV1 during a European ring trial. However, in the Estonian study, the sensitivity of bulk milk testing with gB ELISA was as low as $76.5 \%$ with the true prevalence of $22 \%$ (Raaperi et al., 2010). Therefore, for BoHV1, the bulk milk testing may be used as a rapid auxiliary method of herd screening; however, it is less effective if the herd-level prevalence is lower. In our study, 4 BTM samples from herds with prevalences of seropositive cows from 2.7 to $8.9 \%$ (group C) also reacted negatively in the IBR $\mathrm{gE}$ ELISA. These results confirm the lower sensitivity of the IBR $\mathrm{gE}$ ELISA compared with other tests for milk, which is a major disadvantage of IBR eradication programs based on marker vaccines.
In our study, a significant association was found between BoHV1 infection and BMSCC, which suggests that the pathogen induces not only the drop of milk yield in a herd (Hage et al., 1998) but also loss of quality in the milk. In the univariable statistical tests, BMSCC was correlated with BoHV1 herd status; however, the BMSCC average was the highest in the vaccinated group, which was probably connected to the larger size of those herds which was associated with BMSCC levels. Intraherd prevalence of BoHV1 was found to be related to herd size. The highest prevalence (68-98.9\% of infected cows) was in the group $\mathrm{D}$, in which average cows number was 98.9 (66-186; Table 2 ). Larger herd size was found to be a risk factor for BoHV1 herd seropositivity in previous studies, and it was most likely related to the purchase of new animals of unknown infection status (van Schaik et al., 1998; Van Wuijckhuise et al., 1998). Similar conclusions were drawn independently by Bishop et al. (2010), Williams and Winden (2014), and Raaperi et al. (2010), who found that Welsh, UK, and Estonian farms, respectively, with positive bulk milk antibody titers to BoHV1 were significantly larger in size than the seronegative ones. The association between BMSCC and BoHV1 infection was better explained by the multivariable model in which all the variables were analyzed simultaneously. In this model, BoHV1 herd status was one of the important risk factors with the highest risk of increased BMSCC levels in group D, with herds with over $30 \%$ BoHV1 seroprevalence. This is the first report that suggests that BoHV1 infection may influence BMSCC and therefore affects bulk milk quality. The immunosuppressive nature of BoHV1 may explain this observation. The BoHV1 infection is usually latent, provoking 
subclinical secondary infection episodes. Total bacterial count is not an efficient indicator of subclinical mastitis, which might explain why TBC was not associated with BoHV1 herd status in the current study. Hage et al. (1998) did not find an influence of BoHV1 infection on SCC and milk components, although they noted a significant drop in milk production of the initially seronegative cows during a subclinical infection on a dairy farm. Similarly, Herlekar et al. (2013) did not observe significant differences in SCC of composite quarter milk samples between BoHV1-infected and BoHV1-negative farms; however, in our study, the presence of BoHV1 infection in a herd was confirmed by detection of viral DNA in BTM samples. The mean SCC of BoHV1+/Bacteriology - cows were higher than those of BoHV1+/Bacteriology+ cows. Herlekar et al. (2013) concluded that an increase in SCC in milk was more likely due to bacterial inflammatory infection than to BoHV1 infection. Bovine herpesvirus 4 is also suspected to be a possible predisposing factor of bovine mastitis, and also an agent of secondary udder infections in prolonged mastitis cases (Kálmán et al., 2004). Zadoks et al. (2001) showed a more frequent occurrence of Staphylococcus aureus infections of the udder of bovine herpesvirus 4-seropositive cows.

Our results showed that an increased herd size was associated with a decrease in BMSCC. This has also been shown in other studies and it can be deduced from better farm hygiene on larger farms (Berry et al., 2006; Ingham et al., 2011). Additionally, BMSCC is characterized by some specific fluctuations during the year, which were also observed in the present study. In summer, an increase of BMSCC in all classes of farms was recorded, but it was not statistically significant compared with the other seasons. In the study of Archer et al. (2013), it was shown that the BMSCC was higher in Irish and UK herds in February to August and in January to June compared with other months. The increase in BMSCC was probably related to higher temperature and humidity during this period with an increased risk of mastitis induction.

\section{CONCLUSIONS}

The results of our study showed a clear effect of the BoHV1 herd status on BMSCC. Therefore, the infection might influence the quality of milk in addition to a decrease in milk yield and reproduction losses in dairy herds with high BoHV1 seroprevalence. Further studies including a larger number of herds should be performed to verify this observation.

\section{REFERENCES}

Ackermann, M., and M. Engels. 2006. Pro and contra IBR-eradication. Vet. Microbiol. 113:293-302.

Archer, S. C., F. Mc Coy, W. Wapenaar, and M. J. Green. 2013. Association of season and herd size with somatic cell count for cows in Irish, English, and Welsh dairy herds. Vet. J. 196:515-521.

Barkema, H. W., M. J. Green, A. J. Bradley, and R. N. Zadoks. 2009. Invited review: The role of contagious disease in udder health. J. Dairy Sci. 92:4717-4729.

Berry, D. P., B. O'Brien, E. J. O'Callaghan, K. O. Sullivan, and W. J. Meaney. 2006. Temporal trends in bulk tank somatic cell count and total bacterial count in Irish dairy herds during the past decade. J. Dairy Sci. 89:4083-4093.

Bishop, H., J. Erkelens, and S. Van Winden. 2010. Indications of a relationship between buying-in policy and infectious diseases on dairy farms in Wales. Vet. Rec. 167:644-647.

Hage, J. J., Y. H. Schukken, T. Dijkstra, H. W. Barkema, P. H. van Valkengoed, and G. H. Wentink. 1998. Milk production and reproduction during a subclinical bovine herpesvirus 1 infection on a dairy farm. Prev. Vet. Med. 34:97-106.

Herlekar, D. A., C. S. Shashikant, A. A. Gurjar, and B. M. Jayarao. 2013. Presence of viral and bacterial organisms in milk and their association with somatic cell counts. J. Dairy Sci. 96:6336-6346.

International Dairy Federation. 1999. Suggested interpretation of mastitis terminology. Bull. Int. Dairy Fed. 338:3-26.

Ingham, S. C., Y. Hu, and C. Ané. 2011. Comparison of bulk-tank standard plate count and somatic cell count for Wisconsin dairy farms in three size categories. J. Dairy Sci. 94:4237-4241.

Jacevičius, E., A. Šalomskas, J. Milius, S. Petkevičius, R. Mockeliūnas, I. Jacevičiene, R. Lelešius, and G. Pridotkas. 2008. Prevalence and control measures of infectious bovine rhinotracheitis in Lithuania. Pages 49-53 in Animals Health Food Hygiene, Jelgava, Latvia. Latvia University of Agriculture, Jelgava, Latvia.

Jones, C., and S. Chowdhury. 2010. Bovine herpesvirus type 1 (BHV1 ) is an important cofactor in the bovine respiratory disease complex. Vet. Clin. North Am. Food Anim. Pract. 26:303-321.

Kálmán, D., S. Jánosi, and L. Egyed. 2004. Role of bovine herpesvirus 4 in bacterial bovine mastitis. Microb. Pathog. 37:125-129.

Kampa, J., S. Alenius, U. Emanuelson, A. Chanlun, and S. Aiumlamai. 2009. Bovine herpesvirus type $1(\mathrm{BHV}-1)$ and bovine viral diarrhoea virus (BVDV) infections in dairy herds: Self clearance and the detection of seroconversions against a new atypical pestivirus. Vet. J. 182:223-230.

Kramps, J. A., M. Banks, M. Beer, P. Kerkhofs, M. Perrin, G. J. Wellenberg, and J. T. Oirschot. 2004. Evaluation of tests for antibodies against bovine herpesvirus 1 performed in national reference laboratories in Europe. Vet. Microbiol. 102:169-181.

Nandi, S., M. Kumar, M. Manohar, and R. S. Chauhan. 2009. Bovine herpes virus infections in cattle. Anim. Health Res. Rev. 10:85-98.

Pastoret, P. P., E. Thiry, B. Brochier, and G. Derboven. 1982. Bovine herpesvirus 1 infection of cattle: Pathogenesis, latency, consequences of latency. Ann. Rech. Vet. 13:221-235.

Pyörälä, S. 2003. Indicators of inflammation in the diagnosis of mastitis. Vet. Res. 34:565-578.

Raaperi, K., I. Nurmoja, T. Orro, and A. Viltrop. 2010. Seroepidemiology of bovine herpesvirus 1 (BHV1) infection among Estonian dairy herds and risk factors for the spread within herds. Prev. Vet. Med. 96:74-81.

Rogan, W. J., and B. Gladen. 1978. Estimating prevalence from the results of a screening test. Am. J. Epidemiol. 107:71-76.

Rola, M., M. Polak, J. Rola, L. Bicka, J. F. Żmudziński, and J. Kuźmak. 2005. Bovine immunodeficiency virus (BIV) infection in respect to BHV-1, BLV and BVDV coinfections. Med. Weter. 61:286-289.

Sharma, N. 2007. Alternative approach to control intramammary infection in dairy cows: A review. Asian J. Anim. Vet. Adv. 2:50-62. 
Ståhl, K., H. Rivera, I. Vågsholm, and J. Moreno-López. 2002. Bulk milk testing for antibody seroprevalences to BVDV and BHV-1 in a rural region of Peru. Prev. Vet. Med. 56:193-202.

van Schaik, G., A. A. Dijkhuizen, R. B. Huirne, Y. H. Schukken, M. Nielen, and H. J. Hage. 1998. Risk factors for existence of bovine herpes virus 1 antibodies on nonvaccinating Dutch dairy farms. Prev. Vet. Med. 34:125-136.

Van Wuijckhuise, L., J. Bosch, P. Franken, K. Frankena, and A. R. Elbers. 1998. Epidemiological characteristics of bovine herpesvirus 1 infections determined by bulk milk testing of all Dutch dairy herds. Vet. Rec. 142:181-184.

Wellenberg, G. J., W. H. van der Poel, and J. T. van Oirschot. 2002. Viral infections and bovine mastitis: A review. Vet. Microbiol. $88: 27-45$.
Williams, D., and S. V. Winden. 2014. Risk factors associated with high bulk milk antibody levels to common pathogens in UK dairies. Vet. Rec. 174:580.

Woodbine, K. A., G. F. Medley, S. J. Moore, A. M. Ramirez-Villaescusa, S. Mason, and L. E. Green. 2009. A four year longitudinal seroepidemiological study of bovine herpesvirus type-1 (BHV-1) in adult cattle in 107 unvaccinated herds in south west England. BMC Vet. Res. 5:5.

Zadoks, R. N., H. G. Allore, H. W. Barkema, O. C. Sampimon, G. J. Wellenberg, Y. T. Gröhn, and Y. H. Schukkent. 2001. Cow- and quarter-level risk factors for Streptococcus uberis and Staphylococcus aureus mastitis. J. Dairy Sci. 84:2649-2663. 